\title{
Centrists Vs Salafists on the Islamic Concept of Peace
}

\author{
Sagi Polka* \\ Arabic Language and Islam Department, The Hebrew University of Jerusalem, Israel
}

Submission: May 22, 2018; Published: June 25, 2018

*Corresponding author: Sagi Polka, Arabic Language and Islam Department, The Hebrew University of Jerusalem, Israel, Email: sagipolka@gmail.com

\begin{abstract}
The following article discusses the Islamic conceptualization of peace, juxtaposing wasatiyyah (Centrist) and Salafi Jihad attitudes towards Muslim relations with nonMuslims. The paper focuses on each movement's contemporary response to the various IsraeliArab Peace Treaties. AlAnfal 8, 61 is widely referenced as the "Peace Verse", and a close examination of classical and modern Quranic exegesis of this verse its context sheds a great deal of light on Islam's conceptualization of peace. From this examination we conclude that peace and Jihad are close conceptual kin in the ideological house of Islam, since the verse in question purposes merely to legitimize a hudna (ceasefire) with nonMuslims engaged by Jihad if and where such an agreement serves the Muslim interest, and at all events only for a definite and limited period of time. Some tension is clearly discernable between two Islamic perspectives on the matter: Centrists on the one hand and Salafists on the other, especially the Salafi Jihadists among them. Centrists are pragmatic in that they are willing to exploit juridical tools in order to balance Sharia imperatives with reality. They are well aware of Islam's image in the world, and in the West especially, and so they take great pains to represent Islam as a religion whose essence is peace between Muslims and infidels. The Salafi Jihadists repudiate the peace accords with Israel as these run counter to the very fundamentals of Sharia law. As leader of the Centrist movement, AlQaradawi stresses that jihad is not waged against nonMuslims qua infidels, but against nonMuslims who invade Muslim territory. On these grounds, too, the peace accords with Israel are objectionable

Keywords: Salafists; Peace; Islamic; Globalization; Judaism; Zionism; Critique; Wasațiyya; War; Emperor; Migration; Ideology; Battle; Holy city; Victory; Sword Verse; Idolaters; Traditional
\end{abstract}

\section{Introduction}

\section{AlQaradawi's Response to the Pope's Critique of Islam - Wasațiyya as Islamic PR}

Various Muslim Scholars, not least Egyptian Sheikh Yusuf alQaradawi, raised some claims in rebuttal to Pope Benedict XVI's September, 2006 address in Germany. Ideological light of the wasatiyya or Centrist school of thought, alQaradawi sees himself as ideological heir to Hassan al Banna, founder of the Muslim Brotherhood, in which alQaradawi was formerly a member. The Pope had quoted seventh century Byzantine Emperor Manuel II, who said: "Show me just what Muhammad brought that was new, and there you will find things only evil and in human, such as his command to spread by the sword the faith he preached."

AlQaradawi's response to the Pope is part of a broad-spectrum effort to cultivate a Centrist Islamic discourse in an Age of Globalization, as AlQaradawi writes "Our Islamic Discourse in The Age of Globalization." In the proposed discourse, terror is rejected (marfüd) that results in the deaths of innocents. Nevertheless one must distinguish between the terror just described and the matter of terrifying (irhāb) the enemies of Allah and the Muslims. To terrify the enemy is a divine commandment in alAnfal 8:60, interpreted by alQaradawi to refer to intimidating the enemy so as to avoid allout war. Wasatiiyya seeks to correct the widespread error in understanding the term Jihad, which in its view is far broader in scope than the term qitāl, meaning fighting. Wasațiyya highlights various kinds of Jihad in Islam that do not involve fighting, stressing also Islam's inclination to peace generally [1].

Muslim scholars like Sheikh Yusuf alQaradawi are adamant that Islam not only desires peace, but actively strives for it, peace being a cornerstone of Islamic proselytization ( $\left.d a^{c} w a\right)$. They likewise depict Islam as waraverse, a religion that ever strives to avoid the bloody upshot of battle; and when, alas, the din of war does make itself heard among men, Islam does all it can to diminish its impact and aftermath [2].

Cited in support of alQaradawi's position regarding Islam's peaceable nature is the following:

a. The Arabic words "peace" and "Islam" are derived from the same root, slm. In fact, Quranic exegesis interprets the word silm, as it appears in Surat alBaqara 2, 208, to mean both, since originally silm denotes surrender (istislām), subjugation (to Allah, i.e. inqiyād), and abandonment of quarrel (tark almunāza'a) [3].

b. Islam endears the term "peace" to Muslims in manifold ways, to wit: One of Allah's Good Names (asmā' Allah alḥusna) is alsalām (Surat alHashr 59, 23). The Garden of Eden is also 
called dār alsalām (Surat al'An'ām 6, 127). In prayer, Muslims everywhere recite the altashahhud text, wishing peace upon Muhammad, themselves, and their nation. Prayer ends with the taslīm, the formulaic "Peace and the Mercy of Allah Be upon You", spoken twice, first to the right, then to left [4].

c. Say the scholars, a Muslim does not welcome war, but peace; however, if war befalls him he must wage it with strength and vigor. The idea that Muslims are compelled to war against their will can be traced to Surat alBaqara 2, 16. Likewise, in the Hadith tradition Muhammad speaks the following: "Do not yearn to meet your enemy, and ask Allah for wellbeing. But if you do meet your enemy, endure (the tribulations of war) and know that heaven is under the shadow of the swords."

d. The siege laid by Quraysh and the confederate tribes against Medina, in what is commonly referred to as ghazwat alahzāb or ghazwat alkhandaq (627 A.D.) ended in failure. Indeed, no battle was engaged thanks to Allah's timely sending of angels and a strong wind against the confederate besiegers. The Quran records in Surat alAḥzāb 33, 25: "And sufficient was Allah for the believers in battle (wakafa Allah almu'minin alqitāl)." Al Qaradawi points out that the fact that Allah was sufficient for the believers in battle is a point of divine grace for which the believers must be thankful. Therefore, it is ludicrous to claim that Islam is a warmongering, bloodlusting religion [5].

e. The Quran calls șulh alhudaybiyya, the tenyear truce (hudna) between Muhammad and Quraysh in 628 A.D., fath mubin, a decisive victory, on the heels of which descended Surat alFath. A certain tradition recalls one of the Prophet's Companions asking the Prophet: "Is it [șulh alhudaybiyya] a victory? Said (the Prophet): "Yes, a victory it is." Imputing victory to a truce is clearly the sign of a peaceloving religion [6].

f. If Muslims must fight, they are commanded nevertheless to keep death and damage to a minimum. For example, the Prophet forbade killing those not conscripted to the actual fighting forces. Thus Islam protects the innocent, not least of whom children, the elderly, farmers and merchants [7].

g. The Quran requires (Surat alAnfāl 8, 61) that Muslims acquiesce when sued for peace (silm), even after war has been declared and battle engaged. Even though verse 62 rights after implies that those who sued for peace were scheming deception all the while, nevertheless their suit must not be ignored. The Prophet, complying, struck the Hudaybiyya Treaty with the Quraysh. Explains alQaradawi, this was done not out of weakness or the desire of the Prophet's Companions to avoid out-and-out conflict. Quite the contrary, they had already sworn fealty on pain of death for the sake of the Prophet (Surat alFath 48, 18 - this Oath of Fealty under the tree is known as bay'at alridwān). Muhammad entered into a peace agreement for no other reason than that the Quraysh inclined towards peace (janaḥu lilsilm), and he benefited greatly there from, for many of the Quraysh converted to Islam.

h. According to one tradition attributed to the Prophet, harb or "war" is a most unsightly word. The Arabs of the preIslamic jāhiliyya were wont to name their sons harb, to wit Ḥarb b. Umayya, father of Abu Șufyān [8].

i. Islam prohibits war during the four "forbidden (or holy) months" of the year al'ashhur alhurum. These are: Dhu alQa'da (the $11^{\text {th }}$ month in the Muslim calendar), Dhu alHijja $\left(12^{\text {th }}\right)$, Muharram (1st) and Rajab $\left(7^{\text {th }}\right)$. More specifically, war is forbidden (Surat al Baqara 2, 217) during these months unless Muslims are attacked, whereupon it is essential they reciprocate war (Surat alBaqara 2, 194). All four schools of Islamic Jurisprudence agree that the prohibition on war during the four holy months is abrogated (mansūkh), although there are still some, like Ibn Qayyim alJawziyya, who claim otherwise. Note that the question is not whether Muslims may fend off an infidel attack, but whether Muslims may instigate war themselves during these months.

j. The hajj and the ritual texts associated with it urge the devout towards peace. The hajj takes place during Dhu alHijja, one of the aforementioned holy months, in the "holy city" (albalad alharām) of Mecca, and in a special state of holiness (ị̂rām), when a Muslim may not kill, or even hunt (see Surat alMā'ida 5, 95).

\section{Surat AlAnfāl 8, 61: Interpretation}

In March 200722 member states of the Arab League ratified the "Arab Peace Initiative" which in a previous incarnation, it was called the "Saudi Peace Initiative". The main thrust of the initiative was to end the ArabIsraeli conflict and normalize relations, on condition that Israel withdraw to the borders of 4 June 1967. A Palestinian State would be proclaimed with its capital in East Jerusalem, and a just solution would be found for the Palestinian refugees in accordance with U.N. Resolution 194. The Arabic version of the initiative echoes alAnfāl 8, 61: "The Council [of the Arab League] asks Israel to reexamine her policy and incline towards peace by proclaiming likewise a just peace as her strategic objective".

Ilai Alon, in an article that focuses on the language of the peace initiative, explains that the phrase "incline towards peace" plays an important role in Islamic political theory, underpinning a wide range of international agreements and laws of war in Islam, and famous among Muslims. It is reasonable to assume that its usage here by the Arab League serves not only to invite Israel to parley for peace, but also to uphold the principle mașlaha, the Muslim interest. The upshot is that the Arab League initiative can nevertheless be viewed as their response to Israel's prior inclination towards peace - which, as Muslims, they are obliged to accept, while remaining wary of possible treachery (alAnfāl 8, 
62). This echo of alAnfāl 8,61 is unremarkable since it has become something of a "Peace Verse" in the popular consciousness, and has been amply cited in justification of past peace treaties with Israel, and also as proof that Islam is a religion of peace and religious tolerance.

Yitzhak Reiter, in his most interesting "War, Peace and International Relations in Islam: Muslim Scholars on Peace Accords with Israel" writes that the Quran is equally endowed with peaceable quotations as it is full of warlike ones. Of the most peaceloving is alAnfāl 8, 61. Reiter is rather astonished at the injunction to consent when an enemy inclines towards peace, since that is in direct contradiction to the Jihad mandate against the infidels. Moreover, peace as a concept is unlimited in duration, unlike the more provisional hudna, and so can be construed as permanent for all intents and purposes [9].

Moshe Sharon is convinced, therefore, that Islam's conception of peace is quite different from the Jewish or Christian one. The Jewish and Christian conception stems from the Bible prophecies, where peace is rendered in absolute, eschatological terms: the utter end of bloodshed and unqualified goodwill among men. The Quran does not evince any such reality. When Israel signed the Camp David Accords with Egypt, Sharon points out, Carter wanted to exalt the moment by quoting appropriate verses from the holy books of the three Abrahamic faiths. As a Christian familiar with the Bible, he had little trouble homing in on Micah and Isaiah to find such gems as: "They will beat their swords into plowshares and their spears into running hooks. Nation will not take up sword against nation, nor will they train for war anymore" (Isaiah 2:4). But when the American President charged his aides to locate a likewise quotable Quranic passage, they were at a loss to find the same kind of universally absolute and morally authoritative message. What they did come up with was none other than alAnfāl 8,61 . Sharon concludes that Islam is a militant and aggressive religion, and as such knows only one thing - victory. The Muslim, he writes, is first and foremost a soldier in the army of Allah.

The Encyclopedia of the Quran under "Peace" asserts that peace plays a pivotal role in the Quran and in the life of Muslims; However the term itself mostly appears in conjunction with holy war, i.e. Jihad, and so it must be perceived. This is true of alAnfāl 8,61 as well. Surat alAnfāl descended just after the Battle of Badr between Muhammad and the idolaters of Mecca in 624 A.D. The "Peace Verse" (61) clearly appears in the context of war, as verse 60 immediately prior exhorts Muslims to "prepare against them whatever you are able of power and of steeds of war by which you may terrify the enemy of Allah and your enemy [traditionally understood to mean idolaters] and others besides them whom you do not know [but] whom Allah knows [according to one interpretation, the Jewish tribe of Qurayza [10].

Quranic exegetes have made much of the warlike context surrounding verse 61. For instance, contemporary scholar Muhammad Mutawalli alSha'rāwi (d. 1998), once Egyptian
Minister of Endowments (19761978), asserts that verse 61 follows the "Preparatory Verse" ( $a l^{\prime} i^{\prime c} d \bar{a} d$ ), for Allah wishes to press on the believers that the force they are amassing is not a means of tyranny (tughyān) or war for its own sake. War preparations do not require battle to bear them out, for if the enemy sues for silm then must the Muslims acquiesce [11]. Muhammad Sayyid Tantawi (d. 2010), Sheikh of alAzhar from 1996 till his death, writes in his commentary on the Quran that the Prophet Muhammad was obliged to fight the infidels who were in breach of their agreement with the Muslims, and to prepare to this end a terrifying force (verse 60). However, if those very same infidels were to incline (in the language of verse 61: janahū) towards a truce (Tantawi takes silm in this verse to mean musālama wamușālaḥa), then must the Muslims acquiesce, so long as their interest (mașlaha) is being served [12].

Contemporary Muslim scholarship holds up alAnfāl 8, 61 as proof that MuslimInfidel relations are founded on peace, with the odd conflagration breaking out only when dictated by unfortunate necessity (ḍaūra) [13]. However, detractors are quick to assert that this opinion stands in blatant contradiction of Sharia law, specifically the obligation in Surat alBaqara 2, 216 to engage in Jihad ("Fighting has been enjoined upon you... etc."). Verse 61, they say, means only that Muslims may lay off fighting by means of a hudna (musālama), on condition that it is truly necessary to them (hujja); and this condition is elucidated in Surat Muhammad 47, 35, which enjoins Muslims: "So do not weaken and call for peace while you are superior." It is significant that alAnfāl 8, 61 serves as the fundamental justification of peace with Israel, cited by contemporary Muslim scholars who are in favour. It is therefore important to shed light on its various and multifarious shades of meaning. The verse raises a number of noteworthy exegetical concerns, on both the classical and contemporary levels.

a. What does the word silm mean exactly (it lends itself to multiple readings among different commentators and interpreters of the Quran)?

b. There is a conditional aspect apparent in the verse. On whom does it depend?

c. Is the verse in question abrogated (mansūkh)? And if so, which verse or verses specifically abrogate (nāsikh) it?

d. What does the conditional "in janahū lilsilm" mean exactly? Let's address these questions one by one.

\section{The meaning of Silm}

AlTabari [14] (d. 923) interprets silm to mean cessation of hostilities by means of conversion to Islam, payment of the poll tax (jizya), treaty (muwāda'a, i.e. hudna) or any other means of șulh [15]. Indeed, some Quranic commentators take silm to mean șulh exactly, i.e. truce or hudna (muhādana) [16]. Ibn Kathīr (d.1372), among others, even mentions in this context the hudna of 628 A.D. between the Prophet and the Quraysh tribe in Hudaybiyya, a truce reached after the Quraysh prevented Muhammad and his followers 
from entering the $k a^{c} b a$ and performing the rituals of the 'umra [17]. Other scholars take silm to mean surrender (istislām) [18]. Yet others interestingly interpret silm as synonymous with Islam. Such a tradition is quoted by alTabari as emanating from Ibn Isḥāq [19]. Lastly, some interpret silm to mean simply obedience (țā $a$ ) [20]. Shedding some light on alAnfāl 8, 61, is Muhammad 47, 35: "So do not weaken and call for peace while you are superior; and Allah is with you and will never deprive you of [the reward of your deeds".

This verse forbids Muslims to call for hudna or șulh while they have the upper hand. Scholars have stressed in this vein that where the infidels are stronger and more numerous that the Muslims, and the Muslim leader perceives an advantage in proposing a hudna, only then he may do so. In the exegetical literature the suggestion arises that this verse abrogates or is abrogated by alAnfāl 8, 61 . But many disagree, and infer that a hudna is permissible only in times of necessity, when Muslims are too weak to confront their enemies [21].

\section{To Whom Does the Verse Apply?}

Scholars are at sixes and sevens on this question. Some say it refers to the People of the Book (ahl alkitāb), specifically to the Qurayza tribe, whose male members were slaughtered by the Prophet for having conspired to besiege the city of Medina in 627 A.D. (an event known as ghazwat al a hāāb or ghazwat alkhandaq); or to the tribe of Nadīir, who were exiled by the Prophet from Medina [22]. AlRāzī (d. 1210) cites a tradition according to which the verse descended in relation to the tribes of Qurayza and Nadiir specifically, but construes that a truce is generally permitted, as the phrasing of the verse is generic [23]. Other commentators assert that the verse did not descend in specific relation to the Qurayza, but was always intended to apply generally to Islam's enemies at large [24]. Tantawi comments that the verse affirms the principle that Muslims may parley a cessation of hostilities (musālama) at will, so long as it is in the Muslim interest. Ibn Ashur (d. 1972), a leading Tunisian scholar, held that the verse relates to both polytheists (mushrikūn) and the People of the Book (ahl alkitāb), simply because the versus preceding it relate to the same.

Deciding to whom verse 61 relates bears heavily on its abrogative status as well. Ibn Ashur states, for example, that if alAnfāl 61 relates to polytheists, then it is perforce abrogated by the "Sword Verse" ('âyat alsayf, i.e. Surat alTawba 9, 5) wherein Muslims are commanded to kill polytheists (mushrikūn) wherever they may find them [25]. He reasons on the other hand that if alAnfāl 8, 61 relates to the People of the Book, then it isn't abrogated at all, and the inclination towards silm must perforce be met with the demand for Jizya (see the "Jizya Verse" in Surat alTawba 9, 29) or with an armistice agreement (muwāda'a, meaning șulh).

\section{Abrogation (Naskh)}

Rubin maintains that the various war and peace verses in the Quran, when taken together, seem to imply a general entreaty to avoid war even against infidels. Some tension is certainly elicited here between the two fundamental exegetical approaches to the Quran, the abrogative (naskh), which holds that old law was divinely and deliberately replaced by new law, and the integrative, which holds that Quranic verses simply expired as earthly conditions changed, no abrogation necessary. The obligation in alAnfāl 8, 61 to make peace with an enemy who inclines towards it, does not square with the idea of Jihad, by the lights of which the leaders of the new Muslim community sought to shepherd their people in the first century of Islam. So it became widely accepted that al Anfāl 8, 61 had been abrogated by the "Sword Verse". Still, the integrativists did not concede the debate, and suggested their own interpretation: the verse relates to Jews only, with whom, they explained, Muslims may establish peace by accepting payment of the Jizya, in accordance the "Jizya Verse" in Surat atTawba [26].

Nevertheless, the abrogativists are alive and kicking when it comes to alAnfāl 8, 61, and many scholarly opinions consider the verse abrogated (mansūkh), nominating multiple abrogating verses as potential candidates. According to a tradition related by Qatida and Ikrima, two verses do the abrogating here, namely Aurat alBarā'a 9, 5 and 36. Following this logic, before Surat alBarā'a descended the Prophet might have reached an armistice agreement with the polytheists, during which they could either convert, or find themselves later reengaged in battle by the Muslims. With the descent of Surat alBarā'a, however, Muslims are now commanded to engage the polytheists in battle until they convert, on pain of death (see verse 5). AlTabari does not accept this abrogative view of things, and rules that since alAnfāl 8, 61 relates to the Qurayza tribe who are People of the Book, it is generally permitted to enter a sulh agreement with People of the Book so long as they pay the Jizya. Surat alBarā'a 9, 5, on the other hand, relates to idolaters, from whom the Jizya may never be collected. Tantawi objects that the "Sword Verse" does in fact totally abrogate alAnfāl 8, 61. Nevertheless, if the enemy are many and strong, then Muslims may strike a truce as per the precedent of Muhammad in alhudaybiyya.

Some traditions hold that alAnfāl 8, 61 is, in fact, abrogated by the "Jizya Verse" in Surat al Barā'a 9, 29, and alZamakhshari (d. 1144) quotes just such a tradition emanating from Ibn Abbas [27]. AlQurtubi (d. 671) demurs, saying that the "Jizya Verse" merely teaches Muslims to accept the Jizya from the People of the Book, as was done in the days of the Right Guided Khalifs, and even after. Even the Prophet tolerated an arrangement of this sort with the people of Khaybar, whom he defeated and put back to farm the land on pain of a tax amounting to half their harvest. AlQurtubi quotes another Ibn Abbas tradition, namely that alAnfāl 8, 61 is abrogated by Surat Muhammad 47, 35. As we have seen, this latter prohibits Muslims from showing weakness by calling for peace (in the verse: salm) while they hold the upper hand. Ibn alArabi (d. 1240 ) rules that, although Surat Muhammad 47, 35 affirms that if Muslims are strong and many then they require no șulh with the enemy, nevertheless if the Muslims have an interest (maslaha) in such a șulh, e.g. regrouping, limiting collateral damage etc., then 
there is nothing wrong with instigating a șulh, as was the case in Hudaybiyya.

AlBaghawi (d. 1122) concurs that alAnfāl 8, 61 is not abrogated for it compels Muslims to implement a șulh with an enemy when in the Muslim interest. If the Muslims have the upper hand, says alBaghawi, then the hudna reached should not exceed one full year. However, if the infidels are dominant then the hudna may be stretched to ten years, but not further, as per the precedent set by the Prophet in Hudaybiyya (despite the fact that the Quraysh violated the agreement before it could expire; the Prophet conquered Mecca from the Quraysh in 630 A.D., only two years into the tenyear hudna in Hudaybiyya) [28]. AlZamashkhari artfully concludes that it all depends on the judgment of the Muslim leader concerning the benefit that would accrue to Islam and the Muslims at a given moment from fire or ceasefire - it is not necessary for Muslims to be continually battling, or for that matter to enter any hudna agreement on a permanent basis.

Interestingly, alTabarsi (d. 1153) and alTusi (d. 1067) reason simply that alAnfāl 8, 61 could not possibly be abrogated by verses 5 and 29 in Surat alBarā'a, because the latter descended in 9A.H., and even after they had descended did the Prophet agree to a șulh with the Christian embassy from the Najarān.

\section{Conditionality}

For Muslims to agree to sulh depends on the enemy first inclining towards silm, whether the enemy be People of the Book or idol worshipers. Tantawi is ever suspicious of any such inclination, since the enemy would not so incline unless he were pressed or could gain some advantage there from, and so Tantawi urges great caution on Muslim believers. AlAnfāl 8, 62 clues the Prophet into the idea that the enemy's suit for peace may disguise an element of trickery: "But if they intend to deceive you then sufficient for you is Allah". But the Prophet is commanded to agree to sulh anyway, for Allah is "the Hearing, the Knowing" (see the latter part of alAnfāl 8,61), and "it is He who supported you with His help and with the believers."

AlSamarqandi summarizes the upshot as follows: Islam permits șulh when Muslims are too weak to fight; but when they are strong then it is unbefitting that they should agree to sulh with the enemy, rather they should do battle with him until he converts to Islam, or until he pays the Jizya tax if he is of the People of the Book. The verse's command to make șulh descended to address a Muslim minority that suffers defeat at the hands of strong idol worshipers. Hence, reasons al Samarqandi, the verse does not require Muslims to accept a hudna offered up by the enemy; Rather they must consider their own strength.

Notable Hanbali scholar Ibn Qudama in his book "AlMughni" defines hudna as an agreement reached with People of War (ahl alharb), whereby cessation of hostilities may or may not be guaranteed by a tribute of some sort. Such a hudna is called muhādana, muwāda'a, and mu'āhada, and is permitted according to Surat alBarā'a 9, 1 and Surat alAnfāl 8, 61. Ibn Qudama (d.
1223) goes on to rule that the hudna period must serve the Muslim interest, to wit it must find currently weakened Muslim forces in a new relative position of strength when it expires. Another such interest might include the potential conversion of the enemy, or payment of the Jizya tax in accordance with Muslim law. He qualifies that no hudna may be permanent, i.e. unlimited in duration, for this would lead to Muslims abandoning Jihad. To summarize, alAnfāl 8, 61 appears in a belligerent context, legitimizes a temporary truce in the Muslim interest. Yet the verse is quoted in formal legal opinions by Muslim jurists lending legitimacy to the peace agreements with Israel, not merely cessation of hostilities. The question remains: How did these jurists clear the hurdle?

A Look at the Legal Literature Pertaining to the EgyptianIsraeli Peace Accords and Their Handling of Surat AlAnfāl 8, 61

On 8 January, 1956, then Grand Mufti of Egypt, Hasan Mamoun (d. 1973), propagated a Fatwa on the subject of șulh with the Jews of Palestine. Mamoun ruled that an agreement can be made with an enemy in order to return to Muslims that which was stolen from them, but if that agreement assented to belligerence of any form, then it was null and void as far as Sharia was concerned. Regarding alAnfāl 8, 61, says Mamoun, Muslim jurists permit provisional ceasefire ( $m u w \bar{a} d a^{c} a$ ) with the people of dār alharb if and only if a Muslim interest (maslaha) is served thereby. There is a consensus among jurists that even though verse 61 is general and absolute, it is still limited and conditioned on a Muslim interest being served, as gleaned from Surat Muhammad 47, 35 [29].

An important reference to this verse can be found in a certain Fatwa by Jadd alHaqq 'Ali Jadd al Haqq, Mufti of Egypt (19781982) at the time the Camp David Accords between Egypt and Israel were signed. In it he rules that the Accords do jibe with Islamic Law, and quotes al Anfāl 8, 61 in a number of contexts, as evidence that:

a. Islam is a religion of peace; that it uses war sparingly as a means to secure and protect its $d a^{c} w a$. The Quran, he explains, instructs the Believers to eschew war unless it is absolutely necessary, and quotes Surat anNisā' 4, 90 alongside Surat alAnfāl 8, 61 in support.

b. The fundamental relationship between Muslims and nonMuslims is one of peace; war on nonMuslims is a state of emergency is allowed only provisionally. It is for this reason the Quran rules that if, during the progress of war, one side inclines towards peace, Muslims must acquiesce in order to avoid bloodshed. Jadd alHaqq rules that alAnfāl 8, 61 permits Muslims to craft armistice agreements and truces (mu'āhadāt) with nonMuslims of a temporary or permanent nature, in order to preserve or recover the state of peaceful co existence that prevails by and large between the two. Likewise, according to Jadd alHaqq, the verse permits even a military alliance with nonMuslims to cooperate against a 
common enemy. He quotes alQurtubi's commentary on verse 61, to wit Muslims may instigate a truce with nonMuslims if it serves their interest (averts death, damage, etc.), and cites the same precedents, namely Muhammad's truce with the Jews of Khaybar, and his Hudaybiyya agreement with the Quraysh.

c. Muslim jurists are generally agreed that in matters of hudna and sulh, the head of the Muslim bodypolitic has the right to come to a decision whether or not to enter into such an agreement, so long as it is in the Muslim interest. Jadd alHaqq adds that the jurists base their opinion on Surat alAnfāl 8, 61 and the Hudaybiyya precedent [30].

\section{The Oslo Accords in Islamic Jurisprudence - Al-} Qaradawi Vs Ibn Baz

Before the Oslo Accords were signed in September 1995, two notable contemporary jurists locked horns to debate the Sharia underpinnings of such an agreement. In one corner stood Sheikh Abd al Aziz Ibn Abdullah Ibn Baz (d. 1999), Grand Mufti of the Saudi Arabia and Head of the Council of Senior Scholars; in the other, Sheikh Yusuf alQaradawi, formerly of the Muslim Brotherhood and since the sixties something of a "Global Mufti" living in Qatar. In his Fatwa of December 1994, Ibn Baz permits a hudna with Islam's enemies, both temporary (mu'aqqata), and absolute (muțlaqa). He bases this ruling on alAnfāl 8, 61 and on the sulh precedents set by the Prophet vis àvis the Meccans in Hudaybiyya for ten years duration, and visàvis other Arabian tribes unprovisionally. Says Ibn Baz, necessity (hujja) and interest/benefit (mașlaḥa) are sufficient for an enduring hudna, i.e. one unlimited in duration, qualifying that when the necessity or interest expires, then so does the hudna [31].

AlQaradawi grants that Ibn Baz did not err in his trenchant analysis of pure Sharia law, but objects mightily to the way he applies it to the IsraeliPalestinian reality. The landgrabbing Jews never inclined towards peace; they conquered homes by force of arms and expelled the inhabitants, and only later do they seek peace in order to legitimize the landgrab. The condition stipulated in alAnfāl 8, 61 never materialized in the case of the Jews of Israel; the only relevant verse to the Palestinian issue is, therefore, Muhammad 47, 35. AlQaradawi similarly protests alBaz's second justification, namely that hudna is permissible both temporarily and perpetually. The Israeli Palestinian Oslo Accords hardly qualify as hudna, says alQaradawi, for they recognize Jewish sovereignty on land stolen by force of arms. The whole of Palestine is Muslim land, not Palestinian land for Palestinians to dispose of as they please. Palestine belongs to the Umma as a whole [32].

Sheikh Ibn Baz responds that Muhammad 47, 35 applies only where the oppressed are stronger than the oppressor, and can stand up for their rights. However, when the oppressed are in a position of weakness, certainly they can sue for cessation of hostilities, as Ibn Kathir deduces from this verse. Muhammad parleyed the Hudaybiyya truce with the Quraysh because he deemed it better for the Muslims than continuing the fight. But when the Quraysh later broke the sulh, the Prophet renewed the hostilities, and on the Day of Victory (yawm alfath, the Prophet's 630 A.D. entry into the Ka ${ }^{\mathrm{b}} \mathrm{ba}$ ) took over their territory [33].

We must view alQaradawi's stance on this particular issue in light of his broader attitude visàvis the general IsraeliMuslim conflict. The conflict may very well appear to be over dust and dirt, but its motives and aims are all religious at the end of the day. Any conflict that calls upon a Muslim to defend truth and deny falsehood, establish justice and defy oppression is a religious conflict for the sake of Allah (alQaradawi quotes in support Surat anNisā' 4, 76). Islam requires Muslims to defend Islamic territory, and deems this struggle the holiest kind of Jihad. In fact, waging Jihad to protect Muslim land is a personal obligation (fard 'ayn), and any Muslim killed during such a struggle is a martyr (shahìd). The obligation falls first and foremost on those Muslims who dwell in the conquered territory, but if they are too few, then those in adjacent territories must join the struggle, and so on and so forth until all Muslims everywhere are implicated. The Jews, says al Qaradawi, were motivated by their religion in stealing Palestinian lands, so theirs is by definition a religious war. Muslims, likewise, must stand up and fight by, of, and for Islam: "If they fight us with the Torah, we shall fight them with the Quran; if they have recourse to the Talmud, we shall have recourse to alBukhari and Muslim [referring to the two most authentic collections of Sunni narrated traditions]; if they say 'we observe the Sabbath', we shall say 'we observe the Day of Gathering [Friday]'; if they say 'Temple', we shall say 'alAqsa'; and if they rally to banner of Judaism, we shall rally to the banner of Islam; if they muster their soldiers in the name of Moses, we shall muster our troops in the names of Moses, Muhammad, and Jesus, peace and prayer be upon them, for we are more worthy of Moses than they!"

AlQaradawi sees Oslo as the personal weakness (alwahn alnafsi) against which the Prophet cautioned the Umma in the Hadith: "And Allah will remove the fear in the hearts of your enemies and place in your hearts alwahn [weakness]. They said, "What is alwahn, O Messenger of Allah?" He said, 'Love of this world and hatred of death.' Strengthening his point, he finally calls attention to the fact that even the Quran itself warns Muslims against showing weakness, as Muhammad clearly states [34]. In March 2007,22 member states of the Arab League ratified the "Arab Peace Initiative" which in a previous incarnation, it was called the "Saudi Peace Initiative". The main thrust of the initiative was to end the ArabIsraeli conflict and normalize relations, on condition that Israel withdraw to the borders of 4 June 1967. A Palestinian State would be proclaimed with its capital in East Jerusalem, and a just solution would be found for the Palestinian refugees in accordance with U.N. Resolution 194. The Arabic version of the initiative echoes alAnfāl 8, 61: "The Council [of the Arab League] asks Israel to reexamine her policy and incline towards peace by proclaiming likewise a just peace as her strategic objective".

Ilai Alon, in an article that focuses on the language of the peace initiative, explains that the phrase "incline towards peace" 
plays an important role in Islamic political theory, underpinning a wide range of international agreements and laws of war in Islam, and famous among Muslims. It is reasonable to assume that its usage here by the Arab League serves not only to invite Israel to parley for peace, but also to uphold the principle ma la a, the Muslim interest. The upshot is that the Arab League initiative can nevertheless be viewed as their response to Israel's prior inclination towards peace - which, as Muslims, they are obliged to accept, while remaining wary of possible treachery (alAnfāl 8, 62). This echo of alAnfāl 8, 61 is unremarkable since it has become something of a "Peace Verse" in the popular consciousness, and has been amply cited in justification of past peace treaties with Israel, and also as proof that Islam is a religion of peace and Religious tolerance [35].

\section{The Basis of Muslim Relations with NonMuslims: War or Peace?}

In his important juridical work "Fiqh aljihad", alQaradawi divides Muslim scholars into two camps according to their attitude towards Jihad. "Peaceminded" ( $d u^{\text {" }}$ āt alsilm) are those who believe that peace prevails by and large between Muslims and nonMuslims, punctuated by bouts of war against outsider aggression in order to defend Muslim life, property or land, or to oppose internecine sedition (fitna). AlQaradawi dubs this group difä'iyyūn (defensivists), since they seem to see Jihad as a defensive obligation, and not as a command to instigate aggression. He is openly proud to belong to this group, which reflects to his mind the true nature of Islamic Jihad.

"Warminded" ( $d u^{\text {c }} \bar{a} t$ alharb) are those who believe that war is the default rapport that must pertain between Muslims and infidels, as justified by the very fact of the unbelievers' unbelief and not merely by proximate acts of unbeliever aggression against Muslims or resistance to Muslim dacwa. In this view, the nature of unbelief is hostility per se, while the nature of Islam is propagation and subjugation of infidel tyranny to Islamic rule, and it is through this lens that the Battles (ghazawāt) of the Prophet and the Conquests (futūhāt) of the Companions must be viewed. AlQaradawi calls these hujūmiyyūn (offensivists), for they broaden Jihad beyond mere defensive counteraction. Islam in their eyes is a truth proudly upheld by the Quran and the sword, a proactive calling to compel nonMuslims to convert, pay the poll tax, or fight [36].

The "offensivists" rely on the following:

a. Surat alBaqara 2, 193: "Fight them until there is no [more] fitna and [until] worship is

[acknowledged to be] for Allah..."

b. The famous "Sword Verse" ('āyat alsayf) in Surat alTawba 9,5 , which abrogates some 114 other verses in the Quran, and obligates Muslims to fight infidels always and everywhere.

c. A tradition ascribed to the Prophet: "I was sent with the sword before the Day of Judgement." d. Another tradition that quotes the Prophet: "I have been ordered to fight the people till they

say: 'None has the right to be worshipped but Allah'.' Clearly, war must be waged actively in order to convert nonMuslims.

e. The Prophet instigated offensive campaigns, e.g. the conquest of Mecca in 630 A.D., or ghazwat tabūk against the Byzantine Romans in 629 A.D.

f. The Right Guided Caliphs and the Prophet's Companions also took the offensive initiative, so that their conquests are considered jihād altalab, offensive Jihad that Muslims wreak upon infidels in the infidels' own territory.

g. Juridical consensus that Jihad of the altalab sort is a collective obligation (fard kifäya) on the Umma entire, which means that Muslims generally must raid the lands of the infidels once per year at least.

h. The very fact of unbelief is justification for struggling against the unbelievers, whether or not other more proximate justifications exist, such as actual infidel aggression against Muslims. These proximate justifications only strengthen the fundamental justification, which is unbelief per se.

i. The ideal of subjugating tyrants and wicked regimes under Islamic rule, so that entire nations can meet Islam immediately and be influenced by it directly, resulting in true mass conversion [37].

AlQaradawi proposes that the major bone of contention between the defensivists and offensivists is their divergent interpretations of jihād alțalab (offensive Jihad). All agree that jih $\bar{a} d$ aldaf (defensive Jihad), which involves resistance (muqāwama) and liberation of Muslim lands from conquering invaders, or even invaders who have amassed on the border of Muslim lands and merely threaten to invade, is obligatory for Muslims, not to mention standard across cultures and nations the world over. Jihad alțalab, on the other hand, prescribes preemptive Muslim violence against infidels in order to nip the potential infidel menace in the bud, to surprise the enemy before being surprised by him, as occurred in ghazwat tabūk (630). Offensive Jihad also aims to raze political or physical barriers to Muslim $d a^{c} w a$, so that the infidels might encounter the Islamic message fully and openly.

Though the hujūmiyyūn accuse the difā'iyyūn of opposing all instances of jihād alțalab, this is hardly more than caricature, says alQaradawi, for the difăciyyūn, also known as mu'tadilūn (moderates, as opposed to mushtaddūn, extremists), recognize a number of conditions that would occasion a lawful Muslim invasion of enemy territory. The true bone of contention between hujümiyyūn and difā́iyyūn is whether Muslims are permitted to make war with those who are not at war with Muslims (ghayr almuslimin almuslimūn). The defensives would say no, Islam is hostile only in response to hostility, and peaceful towards those who would keep the peace, citing a slew of peaceable Quranic verses, not least of which Surat alAnfāl 8, 61. The offensivists 


\section{Global Journal of Archaeology \& Anthropology}

maintain, however, that all of these verses are abrogated by the "Sword Verse." On a practical note, alQaradawi points out all of the negative effects of offensive Jihad in the real world, like rejecting the Charter of the U.N., criminalizing membership in the U.N., and opposing the Geneva Accords on POW matters [38]. AlQaradawi quotes an exemplar of this misguided and destructive attitude, a book by Ali Ibn Nafi alUlyani titled "The Importance of Jihad to the Propagation of Islamic Da'wa, and a Retort to Those Who Have Strayed from It ('ahammiyyat aljihād fi nashr alda'wa alislāmiyya walradd 'ala alțawā'if alḍālla fìha)" [39].

Again, the hairsplitting dispute above is informed by a broader clash of worldviews within modern Islamic politics, between the hardcore Salafi Jihad, the ideological foundation of today's Global Jihad, and Yusuf alQaradawi, a Muslim Brotherhood man, who calls his direction wasațiyya, or Centrism. AlQaradawi discerns four categories of juridical misunderstanding among those contemporary Islamists whom he calls the "faction of violence (jamā'at al'unf):

a. Jihad law as it bears on MuslimnonMuslim relations.

b. The legal obligation to forcefully alter what is abominable (munkar), as derived from the injunction to "enjoin good and forbid evil (alamr bilma'arüf walnahy 'an al munkar)"

c. Law relating to opposing Muslim rulers.

d. Law relating to accusations of unbelief (takfir), especially where exaggeration of such accusations is concerned.

Putting this into perspective, Yitzhak Reiter reminds us that contemporary Islamic scholarship is up against trying to bridge medieval Islamic jurisprudence with the new international legal reality of the modern era. Muslim States, including those that legislate officially according to Sharia law like Saudi Arabia and Iran, have accepted both international law and the concept of the Nation State. Both of these ideological frameworks are inimical to classical Islam, forcing Sharia scholars to seek creative juridical solutions for modern happenstances, in the mundane service of legitimizing Muslim state regimes and the political status quo [40].

\section{Paragon of a Pragmatist: Sheilkh Wahba alZuhayli}

Reiter calls reformists those who seek to mold Sharia around contemporary global politics. Note that they are not trying to change that reality, only to render Sharia relevant in a modern sense. One such reformist is the Syrian Sheikh Wahba alZuhayli (born. 1932), who berates those Western scholars who claim that Islam disingenuously makes truces only to regroup and attack later [41]. Șulh with the enemy is a root ('așl) in Islam; war is ever the exception. So teaches the Quran in Surat alTawba 9,1 and in Surat alAnfāl 8,61. The latter verse, according to alZuhayli, concerns not only People of the Book, for the Prophet made a tenyear peace pact with the idolaters of Hudaybiyya. Neither is the verse abrogated by the "Sword Verse" (Surat alTawba 9,5), for there is no contradiction between them. The Sword Verse relates uniquely to idolaters, while alAnfāl 8, 61 compels Muslims to accept șulh when the right conditions prevail. The proof is in Surat alNisā' 4, 94: and do not say to one who gives you [a greeting of] peace: 'You are not a believer' and in surat alBaqarah 2, 208: "O, you who have believed, enter into Islam completely [lit. "in silm", i.e. peaceably] and do not follow the footsteps of Satan. Indeed, he is to you a clear enemy."

At the commencement of war, elaborates alZuhayli, Muslims offer their opponent three choices:

i. Convert to Islam;

ii. Pay the poll tax (Jizya), which is considered a perpetual șulh; or

iii. Fight.

All this holds where Muslim war preparations (which they are commanded to undertake in alAnfāl 8, 60) have proven insufficient to terrify the enemy, who in turn remains belligerent and does not incline towards peace. If, however, war preparations do terrify the enemy into forsaking aggression and inclining towards peace, then peace must be made with him, in accordance with Surat alNisā' 4, 90: ... so if they remove themselves from you and do not fight you and offer you peace, then Allah has not made for you a cause [for fighting] against them. AlZuhayli then goes on to rule that the resulting șulh can be provisional (șulh mu'aqqat) or perpetual (șulh mu'abbad). The provisional version is called muwādaca, mu'āhada, musālama, and muhādana, and involves a timelimited cessation of hostilities, perhaps in return for some sort of tribute or compensation, where the enemy may remain faithful to his religion, and is not subject to Islamic rule. This temporary șulh is grounded in alAnfāl 8,61, and must be honored by Muslims as per Surat al Mā'ida 5, 1: "O you who have believed, fulfill [all] contracts" and Surat alTawba 9, verses 4 and 7 respectively: "... so complete for them their treaty until their term [has ended]" and "So as long as they are upright toward you, be upright toward them."

The temporary șulh must fulfill three vital conditions:

a. Islamic interests must be paramount.

b. The agreement must be free from corrupt stipulations (alshur alf sida).

c. It must be limited in duration. Notable are the correct stipulations (alshur).

Most essential of all is the temporary duration of the sulh, for, writes alZuhayli, if it is anything but temporary it would constitute repudiation of Jihad. He elaborates that it is really up to the Muslim leaders to evaluate the provisions of any sulh agreement, guided as always by the Muslim interest, and bearing in mind that șulh could never amount to actually repudiating Jihad, after all, Muslims and Muslim proselytizers ( $d u^{\text {“ }} \bar{a} t$ ) always and forever have recourse to Jihad when they are attacked. AlZuhayli faults the approach of many scholars, who reason that hudna must be temporary because a state of war generally pertains between Muslims and nonMuslims and the hudna is a means of renewing 
and reinvigorating holy war. Quite the contrary, says alZuhayli, the fundamental relationship between Muslims and nonMuslims is peace; a permanent treaty can be reached if it allows Muslim $d a^{c} w a$ to propagate peacefully, unimpeded.

How long, then, is hudna allowed to last? The Shaf'i School of jurisprudence maintains that if the Muslims have the upper hand, then no less than four months, but certainly less than one year. The fourmonth minimum is based on Surat alTawba 9, 12, and on the precedent set by Muhammad in his fourmonth hudna with Șafwān bin 'Ummayya, in 630 A.D., during his conquest of Mecca. Less than one year is reasoned from the fact that after one full year has passed, Jizya must be collected. On the other hand, if the Muslims are the weaker party, then hudna may last up to ten years. And if the Muslims are still not strong enough to renew the fight when the hudna expires, then the Muslim leader can renew it as he sees fit. AlZuhayli explains that alShafici laid down this ruling when the Muslims were generally powerful and victorious, but today jurists must take into account the enemy's willingness to sign a temporary treaty. Likewise, it is important that the hudna not serve merely as a time of reconsolidation and war preparations, but should be used wisely to cultivate a livable peace, which is always preferable to war.

Perpetual șulh, on the other hand, serves as a kind of tributary or patronage contract ('aqd aldhimma) sanctioned by the "Jizya Verse" (Surat alTawba 9, 29) [42].

\section{Yusuf alQaradawi and Wasatiyya Weigh in}

Spiritual guide of the wasațiyya, or Centrist, movement, alQaradawi tries, as a matter of course, to steer a golden mean between the Scylla and Charybdis of extreme opinion [43]. He suffers his fair share of fiery tonguelashings from his salafiyya opponents for this behavior, including allegations of heresy leveled by Sheikh Abu Basir alTartusi [44]. AlQaradawi's past involvement with the Muslim Brotherhood is significant, as he equates the Brotherhood's way with Islam's Golden Mean [45]. To him, peace pertains normally between Muslims and nonMuslims; war is the exception [46].

Wasatiyya is an ideological movement that derives its name from Sūrat alBaqara, 2:143, in which the centrist idea appears a distinguishing feature of Islam, insofar as it seeks equilibrium (tawāzun) between two parallels or contrasts, for example, between spiritual and material, realism and idealism etc. Sheikh Yusuf alQaradawi is considered today's foremost proponent of the wasatiyya movement, whose opinions reveal the strong influence of Rashid Reda (1935) and the AlManar Circle, Hassan AlBana, AlQaradawi's esteemed teacher, and various other theorists of the Muslim Brotherhood, namely Sheikh Muhammad alGhazali (1996). The Muslim Brotherhood is kindred to wasațiyya, and it was mainly the Brotherhood who popularized the Centrist approach among contemporary Muslims. Wasațiyya believes in: leniency (taysīr) in legal rulings (fatwa), evangelization (tabshīr) by preaching and proselytizing, and squaring authenticity (aṣāla) with contemporary practice, or in other words, salafiyya with innovation (tajdid). AlQaradawi stresses the core virtues of wasațiyya:

a. Belief in the wholeness of Islam (shumūl alislām), i.e. the allencompassing quality that incorporates faith/dogma ('aqìda) and religious law ( $\operatorname{sharî}^{-} a$ ), proselytization ( $d a^{c} w a$ ), politics and government, knowledge and deed etc.

b. Concerning religious innovation (tajdīd) and ijtihād, the latter should only be performed in matters that are not certainly defined by the faith (qațiyyāt). Such being very few in number, most issues are open to ijtihād.

c. A gradual approach is wise and principled, applicable equally to $d a^{c} w a$, legal and social matters.

d. Legal rulings vary according to time, place, circumstance and custom; so that while the religious ends remain fixed, the means of achieving them are flexible.

e. Certain new understandings (fiqh) are welcome: understanding the ways of Allah in the world and the intents (maqāșid) of Sharia law, understanding the balance of positive and negative in all matters, understanding priorities among courses of action, and properly understanding reality (fiqh alwāqi $i^{i}$.

All of these paint wasatiyya as an essentially pragmatic movement, and by extension its leaders, not least of whom alQaradawi, as eminently worthy to lead the Islamic Awakening (alșahwa al islämiyya) that began in the 1970s [47].

In the section describing wasatiyya's defining characteristics (ma'ālim), alQaradawi devotes considerable space to what he terms "Peace \& Jihad". Here he states that wasațiyya counsels peace always and everywhere with any party who sues for it, an attitude born of a strong desire to protect mankind from unnecessary, destructive wars. The movement likewise pursues international peace accords and leans towards peace (aljunūh ila alsilm; paraphrasing verse 61 in Surat alAnfal, 8) wherever possible. However, wasațiyya also means commitment to Jihad in the name of Allah in order to protect the religion and the holy places; to defend the Nation of Islam and its territorial integrity; to stand up for the disenfranchised against the arrogant Pharaohs, meaning Muslim tyrants who do not rule according to Sharia. Wasațiyya furthermore strives to prepare (i'd $\bar{a} d$ ) a military force strong enough to intimidate the enemy. The imperative verb "prepare" that begins verse 60 is itself part of the Muslim Brotherhood logo. Wasatiyya postulates various types of Jihad, namely: apiritual Jihad, $d a^{c} w a$ Jihad, civilian (madaniyy) Jihad, Jihad against despotism and against individual corruption, all of which exist alongside military Jihad. Indeed, also part of Jihad is the commandment to enjoin the good (al'amr bilma'aruf) and to Forbid Evil (alnahy 'an almunkar), and to change evil by hand, by tongue or, at least, by heart [48].

Yusuf alQaradawi qua wasațiyya spokesman emphasizes that Islam does not despise the apostates on account of their apostasy 
per se, but on account of their aggression. This can be learned from various Quranic verses, to wit alBaqara 2:190, which forbids Muslims from being the aggressor. Guidelines for Muslim relations with nonMuslims were established in alMumtahana 60:89, says alQaradawi, wherein Muslims are enjoined to act justly (watuqsiț $u$ ) towards nonMuslims, in this case idolworshipers, meaning they are to accord them full rights; and also to show them kindness (birr), meaning to afford them more than is their right. This behavior applies only to such non Muslims as have not made war against the Muslims on grounds of religion, and have not driven them from their homes. The same behavior and conditions must apply a fortiori to the People of the Book, ahl alkitāb, who merit special consideration given that a Muslim may take a bride from among them (Surat alMa'idah 5:5). AlQaradawi holds explicitly that ahl alkitab have Dhimmi status (ahl aldhimma), are part of the House of Islam (dar alislām), meaning that as residents of Muslim countries they possess equal rights and obligations to Muslims, religious matters withstanding. Therefore, says alQaradawi, the contemporary term citizen (muwāțin) can replace the ancient dhimmi idiom [49].

AlQaradawi discusses alAnfāl 8, 61 at great length in his comprehensive juridical work "The Law of Jihad" (fiqh aljihād), and his view of the verse can be summarized as follows:

a. War between Muslims and enemies should end in sulh if the enemy inclines towards peace and sues for it. Such a hudna may last upwards of ten years, so long as the Muslim interest (mașlaḥa) is served [50].

b. The "Sword Verse" does not abrogate those dozens of verses that urge forbearance towards nonMuslims, and that includes alAnfāl 8, 61 [51].

c. AlAnfāl 8, 61 is central to proving that Islam reciprocates peace generally, and does not make war except against its aggressors or those who oppose its $d a^{c} w a$ [52].

d. Even if the enemy suing for peace is obviously doing so treacherously, still the Quran urges Muslims to acquiesce [53].

Our understanding of alQaradawi's opinion here would be even more complete if we note that Israel is the only country on earth today that he classifies as dār alharb, everybody else dwelling in either dār alislām or dār al'ahd [54]. The classic dār alislām versus dār alharb dichotomy, [55] which was a cornerstone of classical Jihad doctrine, has given way to a tripartite distinction, now that Muslim minorities flourish in so many nonMuslim countries [56]. The ubiquity of these minorities renders many countries, to borrow a term coined by alShaf'i, dār al'ahd, (or dār $a l d a^{c} w a$ ), denoting places where Muslims enjoy full freedom of religion despite being a minority, so that Jihad correctly assumes the form of proselytization in place of outright armed struggle.

According to alQaradawi, all those countries with a Muslim majority are dār alislām, even those countries that do not legislate according to Sharia law, and even those, which, like Turkey, openly declare themselves secular. Suffice that they were historically
Muslim, that most of the population is still Muslim, and that the leaders are Muslim. Not to mention, they still retain their Muslim character, what with public Muslim holidays and Friday prayers, erection of new mosques, etc. Furthermore, most of these countries claim constitutionally that Islam is their official religion, and that Sharia is a primary fount of legislation, if not its only source [57]. The rest of the world but Israel is dār al'ahd or "House of Contract." The U.N. Charter binds Islam and the Muslims with the rest of the world, and so must be honoured, except where it is in direct contradiction with the Muslim religion and Sharia law [58].

Only Israel is dār alharb, against which Muslims must unite in Jihad. AlQaradawi does entertain the view that countries with separate peace treaties with Israel might be exceptions, as they must now consider Israel dār hudna. Even so, such treaties are a disservice to the Muslim interest at large and harm the Umma, when their purpose and justification must be exactly the opposite [59].

\section{Against Accords with the Jews - the Salafi Jihad Position}

One of the most salient aspects of the Islamic movements of the current generation is their attempt to impute to their struggle against Israel, Judaism and Zionism a perpetual historic dimension by tracing it back to the time of Muhammad and incipient Islam. In Islamic terms, a struggle pertains at all times between Islam's inherent Truth (alhaqq) and the heretical lie (albāțil) sustained by the Jews. Radical Muslim thinkers fault their progressive, peaceinclined counterparts on the grounds that it is war that must form the fundamental relationship between Islam and nonMuslim nations, for Islam does not formally recognize dār alkufr except as a synonym of dār alharb [60].

In "Fiqh alJihad", alQaradawi conceives of wasațiyya as a medium between two extremes. The one extreme he calls "the group that declares war on the whole world". The other he calls "the group that wants to kill Jihad". He considers the former group to uphold the following:

a. Heresy alone is a sufficient condition for engaging nonMuslims violently.

b. The "Sword Verse" abrogates tens of Quranic verses and Hadith traditions that urge Muslims to treat kindly (birr) and justly (qist) with nonMuslims who have not made war against the Muslims on grounds of religion, and have not driven them from their homes, as per Sūrat alMumtahana 60:8.

c. The UN Charter is objectionable because it prevents the 'Umma of Islam from performing Jihad, compelling them to respect international borders and to solve disputes peaceably.

d. The spread of Islam was by the sword and by Jihad.

This way of thinking adversely effects on young Muslims, says alQaradawi, for it drives them to take up arms against their coreligionists, whom they lump together with every other kind of 
infidel after deeming them apostates of Islam (murtaddūn). They declare as unbelievers all who disagree with them, even religious scholars ('ulamā'). They ignore the Islamic prohibition against killing innocents, and thereby open Islam to accusations of undue violence. Some go so far as to kill people completely unrelated to themselves, like tourists, airplane passengers and others in order to terrify, and in thereby open Islam to accusations of terrorism. AlQaradawi controverts the dubious claims of this extreme group by describing the truly Islamic approach, a wasațiyya approach as it were. This way he challenges alQaeda, and the entire edifice of Salafi Jihad reasoning that informed and drove alQaeda's predecessors to act as they did [61].

The term "Salafi Jihad" [62] has gained traction lately among academics in reference to the ideology typical of agents of Global Jihad, like alQaeda. However, ideologues in this vein such as Abu Muhammad alMaqdisi contest the label on the grounds that the term Salafi doesn't apply to those who abandon Jihad and whore after false gods (tawāghïth), indicating "Traditional" Salafism (alsalafiyya altaqlīdiyya).Abu Muhammad alMaqdisi (b. 1959) is one of the foremost ideologues in the Salafi Jihad movement [63]. In his view, both parties signed to the peace accords, Jewish and Muslim alike, are apostates. Moreover, the apostasy of the Muslim governments is worse that the apostasy of the Jews. Therefore, religious scholars need not engage the dubious justifications put forward by government spokespersons, nor refute their indefensible use of Quranic verses, e.g. quoting al Anfāl 8:61 to justify the peace treaty that they signed. The very fact that they attempt to justify such treaties by quoting the Quran is a form of despicable perjury, since it is obvious that in their eyes, contemporary, secular law is the arbiter of what is permitted and what is forbidden, not Sharia. Their religion is really democracy, rule of the people by the people and not by Allah.

The Peace Accords themselves do not constitute an agreement between States of equal standing; rather they are terms of friendship, dependence (ta'biyya), and cooperation, like those which the Hypocrites (almunāfiqūn) in classical times made with the Jews of Medinah. AlMaqdisi reminds us nevertheless that if peace accords benefit Muslims at large and prevent bloodshed, then they should not be derided. This, he says, is in line with Ibn Taymiyya's legal opinion stating that the Mongolian predilection for wine should not be derided, for so long as the Mongol drinks wine his mind is not bent on killing Muslims and stealing their property [64].

AlMaqdisi maintains that the expression "Salafi Jihad" was welcomed by the traditional Salafists for it was given by wellwishers who studiously avoided the various slurs invented by the godless Muslim rulers, slurs like "those who accuse of unbelief" (takfiriyyūn), Kharijites (khawārij), alluding to the group that abandoned Ali at the Battle of Siffin (657), the straying faction (alfi'a ald̄alla), the rebels (albughghah) and the like [65]. Some Western researchers equate Salafi Jihad with those who seek to realize political aspirations by means of violent Jihad. This analysis originated in the 1960s in Arab countries, championed by none other than Sayyid Qutub, the Egyptian author, educator, Islamic theorist, poet, and Brotherhood member who was executed in 1966 in Egypt after having achieved notoriety as the father of revolution in Sunni Islam [66].

Reuven Paz maintains that Global Jihad has been identified as Salafi Jihad since its inception in the mid1990s, especially since the two paradigmatic phases of jihadist terror, namely September 11 and May 2003. Paz further argues that based on new doctrines tendered by Salafi Jihad thinkers, and ongoing debates with other Salafi schools of thought like Traditional Salafism (salaffiyya taqlïdiyya or salaffiyyah 'ilmiyya), the Muslim Brotherhood, and Wahhabism; and based on its impressive internet presence, Salafi Jihad is considered by Jihadi activists and sympathizers as an independent school of thought that is currently undergoing a dynamic process of consolidation around the doctrine of the "oneness" of God (tawhīi) [67]. This Salafi Jihad movement espouses a few basic principles:

a. Belief in the "oneness of God" (tawhīd), of which there are three kinds: Oneness of Lordship (tawhīd alrububiyya) the creator god has certain powers that cannot be attributed to any other being; to do so is heresy. Oneness of Godship (tawhìd aluluhiyya) - only the creator God is worthy of worship; to worship another is heresy. Oneness of Names \& Attributes (tawhīd alasmā' walsifät) - the names of Allah in the Quran are to be understood literally, without interpreting them (ta'wīl), or ignoring them (tactīl) [68]. Al maqdisi subsumes the Oneness of Lordship (alhākimiyya) inalienably under the Oneness of Godship, for the former cannot but mean obeying Allah alone as Lord, Judge and Lawgiver [69].

b. Understanding that faith ('îmān) is a statement (qawl), a deed ('amal), and an intention (niyya). Faith grows through obedience ( $\operatorname{ta}^{\mathrm{a}} a$ ) to Allah and diminishes with insubordination (macșiya)

c. Belief in the Principle of Loyalty \& Disavowal (alwalä walbarā') - Loyalty and Friendship to those who are faithful to Allah, disavowal and enmity towards those who are not faithful to Him [70].

d. Jihad will endure until the Day of Judgement, whether a Caliphate exist at the time or not.

If an infidel attacks that which is sacred to Muslims (harāmāt almuslimin), then Jihad is a personal obligation (fard 'ayn). The apostasy of Muslims from Islam (irtidād) is graver than the original apostasy shown by the likes of Jews and Christians. Therefore, Jihad is to be directed at the socalled "enemy within", at the Muslim rulers who do not rule according to Sharia Law, and at the "enemy without", what is sometimes referred to as the "Zionist Crusader Alliance".

e. Salafi Jihad divides on the question of accusing Muslims of unbelief (takfir). On the one hand are those derogatorily referred to as "exaggerators" (ghullāh), who hold as a fundamental premise (așl) that all Muslims are assumed 
apostates until proven otherwise. Contrast the view that places where Apostasy Laws hold and Islamic Law does not are deemed part of the House of Apostasy (dār alkufr); nevertheless it does not follow that all residents of such places be accused of unbelief. After all, the Islamic State is nonexistent by definition in dār alkufr, and those who govern are likewise murtaddūn. On the other hand are the nonexaggerators, who hold that, where individual accusations of unbelief are concerned, a person is considered a Muslim who speaks the two primary Confessions of Faith, and does not commit any of the ten Nullifiers of Islam (nawāqid alislām) as enumerated by Muhammad 'Abd alWahhab. The reason for this is that a man can judge another man based only on what is visible (zāhir) outside, but only Allah can judge the secrets (sarā'ir) that are hidden inside. The Salafi Jihad movement invokes the principle of Divine Mandate (hākimiyyat Allah) to justify their stated objective of overthrowing all Jahili governments. Their interpretation of the principle is such as to consider such government's apostate from Islam.

f. Religious observance is by a Quran that guides (qur'ān yahdi) and a sword that conquers (sayf yanșur), such is the tagline of Abu Muhammad Almaqdisi's comprehensive website, minbar altawhīd waljihād [71].

It will be interesting to see what shadows are cast by the light of this Salafi Jihad approach on the various Peace Accords with the State of Israel. Salafi Sheikh 'Abd alRahmān bin Abd alKhāliq (b. 1929) from Kuwait writes in his book "Laws of Șulh and Peace Treaties with the Jews: the Muslim Positions [Derived] There from (ḥukm mu'āhadāt alṣulḥ walsalām ma'a alyahūd wamawqif almuslim minha)," that the three accords signed between the Jews and Arab States are null and void from the Sharia point of view, and nothing written in them may be carried out except under duress. He explains in his ruling that the Jews are eternal rivals of the Islamic Umma since the time of Muhammad and until the Day of Judgement. Whoever thinks that the animosity and hatred between Jews and Muslims will cease one day is in denial of Allah's promise, and so whoever seeks to lessen said antagonism is an infidel. A Muslim must never associate in his heart love for Allah and the Believers and loyalty to the enemies of Allah (Surat alMumtahana 60,4). Abd alKhaliq is clear that antagonism and war are the order of the day when it comes to Muslimsinfidel relations, based on alAnfāl 8, 39. Allah allows Muslims to sue for peace with the infidels in only two circumstances:

First, when the infidels weaken and incline towards peace (Abd alKhaliq writes: "wayajnahū ila alsilm" per the verbal idiom that appears in alAnfāl 8,61); In this case cessation of hostilities serves the Muslim interest, since the infidels' belief in the power of Allah must have grown stronger as they grew weaker, and they must now be open to accept Islam. So it was with the Treaty of Hudaybiyya with Quraysh, where the Prophet inclined towards peace only after Quraysh showed their inclination. Second, when șulh is the least of all possible evils, and wards off truly horrific damage, like the șulh the Prophet made with the Ghațafān tribe during the siege of Medina (in 627 A.D., known as ghazwat al$a h z \bar{a} b)$, in return for which he promised half of the Medinan harvest. This șulh served to break the GhațafānQuraysh alliance and allow the Prophet to focus his struggle on Quraysh alone.

Muslims may not sue nonMuslims for peace except in these two cases alone; they must not succumb to the temptations of this world, sloth in Jihad, or trepidation before of the vast number of infidels. This last is a particularly detestable motive for șulh, for it is Allah's way in the universe to give victory to the few over the many (Surat alBaqara 2, 249). To leave off war absolutely and conciliate with the infidels is heresy, and deserving of excommunication from the Muslim community of believers. It would mean repudiating the Jihad that Allah commanded Muslims to observe until the Day of Resurrection, as per alBaqara 2, 216 and a Hadith attributed to the Prophet: "There is no migration after the Conquest [of Mecca], but Jihad and good intention (niyya) [remain]."

Abd alKhaliq rules that a Muslim leader may not enter into a șulh with infidels, if it stipulates a condition in contradiction of the Quran, the Sunna, or the Islamic religion. He may accept only what is permitted, e.g. a hudna of limited duration, such as the Prophet contracted with the Quraysh in Hudaybiyya for 10 years, or a hudna of indeterminate duration, such as the Prophet granted the Jews of Medina. It would be insufferable to accept any agreement that required Muslims to renounce some aspect of their religion, like prayer, fasting, or Jihad, or that required them to rule according to anything other than Allah's perfect word. The contemporary agreements signed between the Jews and the Arab States are voided over and over again by the following catalog of unacceptable stipulations:

a. War between Jews and Muslims is to be ended permanently.

b. The ancient animosity and hatred nurtured hitherto between the two sides is to be mitigated, including the Sharia texts that urge it. This contradicts a root of faith that distinguishes a Muslim from an infidel, and deems an infidel an enemy until he converts to Islam.

c. Jewish sovereignty is recognized over the land of Palestine. Jews conquered by force of arms ('anwatan) a land that had already been conquered by Muslims and whose people had already converted to Islam. It is therefore Islamic land, and cannot be alienated from Muslims, who must strive to reconquer it.

d. The signatories did not advise with the Muslim people before ratifying the treaties. By dint of this alone it is therefore void ('aqd bātili). Arab leaders, claiming to represent various Muslim bodies politic - Egypt, Jordan, and Palestine - signed the treaties based on national and geographical considerations; Considerations whose nature is to sow division and discord 
throughout the Muslim Umma at large. A treaty signed by the leader of a mere NationState is not binding on Muslims in general because the Umma never delegated its rightful decision or the weighing of its broad interests to such narrowly motivated deliberation.

e. The treaties were signed under duress ('uqūd al'ikrāh), by national leaders that did not advise with the Muslim people or with religious experts, such as would have declared any such accord dead on arrival. Just like a contract that sanctions interest on loans, prostitution (zina), theft, highway robbery, or the murder of a Muslim, the peace treaties with Israel sanction abandoning Jihad and fraternizing with the infidel enemy. No treaty or contract can be allowed to drive a wedge between a Muslim and his Umma, his religion, his history or his culture.

f. The treaties inflict such damage both spiritually and objectively, that the Muslim interest is completely overwhelmed. It is therefore illicit res ipsa loquitur, rules Abd alKhaliq, who catalogs the following damaging stipulations in the treaty: (1) Trade barriers will be removed and Israel will have access to Muslim markets; (2) The Jewish State will be contiguous with the Islamic Umma; Jews will thus be able to move about freely within the Arab Muslim body politic, where they will sow seeds of discord and hatred among Muslims; (3) Muslims will leave off Jihad, which is akin to repudiating the one true faith of Islam. Furthermore, Palestinian autonomy is a disgrace, for it is the Jews who grant the Palestinians the right to rule over portions of what nevertheless remains Jewish land.

Abd alKhaliq concludes practically that Muslims everywhere must work to obliterate these peace treaties, for they are an abomination (munkar) that must be put right by each Muslim according to his ability, to quote the famous Hadith. He rules that so long as the Jews cling fast to their false faith, Muslims must defy them. Now would be a good time to recall the work of Abdullah Azzam (assassinated in 1989), spiritual mentor and companion of Osama Bin Laden and founding father of Global Jihad, regarding treaties with infidels. In his book "Defending Muslim Lands is the Most Important of the Personal Obligations (aldifā' ' an arādi i almuslimīn 'ahamm furūḍ al'acyān)," Azzam rules that Muslims may enter into an agreement ('aqd mu'āhada) with infidels, so long as:

a) The treaty serves Muslim interests, naturally

b) The case is NOT one where Jihad is a "personal obligation" (e.g. an enemy invasion of Muslim land renders Jihad fard 'ayn and treaties forbidden)

c) The treaty does not stipulate any of the following:

i. Recognition of infidel title to Muslim land. Muslim land belongs to Allah and to Islam, and cannot be negotiated away by mortals. Just as the Russians do not merit negotiation, but must first relinquish all of Afghanistan, so too must the Jews relinquish the Land of Palestine. ii. Outright negation of any point of Sharia law - so, says Azzam, the Russians may not intervene in government of Muslim Afghanistan, because that would corrupt the Jihad - or conditional contradiction of Sharia law, e.g. permitting idolaters to dwell in Saudi Arabia, or returning a Muslim woman to the infidels (Surat alMumtahana 60,10). As concerns returning a Muslim man to the infidels, jurists are divided, some permitting it on the basis of the Hudaybiyya precedent, and others prohibiting it on the grounds that Hudaybiyya was exceptional to the Prophet.

iii. Disgrace to Muslims, cause for humiliation of any sort.

iv. The rights of infidels to publically exhibit their religion, e.g. building a church or delegating a Mission among the Muslim public. On these grounds alone any political compromise negotiated in Palestine can be rejected outright.

Interestingly, Azzam cites alAnfāl 8, 61, requiring that the Russians recognize Afghani warriors of Jihad and ask for a șulh, as a precondition to peace negotiations.

\section{Summary}

A look through classical and contemporary Quranic exegesis leads one to conclude that alAnfāl 8, 61 descended in the context of war to permit temporary cessation of hostilities (hudna or șulh) in the Muslim interest. A concordant study of the word silm shows that this cessation of hostilities can in no way be construed as a fullon perpetual peace agreement, but only a provisional truce. Such a truce can be open-ended if a tributary arrangement can be made that includes a poll tax, but this only applies to People of the Book. Nevertheless, alAnfāl 8, 61 is cited by contemporary Muslim jurists as justification from a Sharia perspective of the various IsraeliArab peace treaties, e.g. the Camp David Accords. They reason that the hudna is allowed to be openended in this case so long as the Muslims are the weaker party, and so it is a permanent agreement for all intents and purposes.

The question remains, however, how does this square with the Muslim obligation of Jihad? This is really a question of what constitutes the fundamental relationship between Muslims and non Muslims and infidels, and here jurists are divided. Pragmatists hold that Islam fights nonbelievers in response to initial aggression against Muslims. Nonpragmatists are adamant that nonbelievers are targets of Jihad per se, for very fact of their unbelief is hostile to Islam. Both opinions maintain that a Muslim has a personal obligation to engage in defensive Jihad if the enemy invades Muslim territory. It is in this context that we must view the debate concerning the provisional nature of peace with nonMuslims as stated in alAnfāl 8, 61, between alQaradawi's centrist wasatiyya thinking, and the more Jihadintensive salafiyya ideology. Israel, he maintains, does not fulfill the condition laid out it alAnfāl 8, 61, i.e. does not incline towards peace, having invaded Muslim territory. Israel must therefore be struggled against.

Unlike the Salafi Jihadists, alQaradawi, alZuhayli and their ilk do adopt a realistic attitude that recognizes the global 


\section{Global Journal of Archaeology \& Anthropology}

phenomenon of nonMuslim sovereignty over Muslim minorities in many countries, and Muslim membership and participation in international organizations, such as the U.N. AlQaradawi believes that a centrist approach is necessary in order to be flexible enough to achieve Muslim ends by realistic means. Centrist ideologues view themselves as representative of Muslim pragmatism, which they describe as "flexible means to fixed ends." They use juridical tools like the principle of mașlaha in order to bridge perfect Muslim Law and imperfect reality, an approach Salafists despise. It is no wonder, then, that Salafists see the Sword Verse as underpinning MuslimnonMuslim relations, while Wasatists leave that to Surat alMumtahana 60, 89, which enjoin Muslims to display kindness (birr) and righteousness (qisț) towards nonMuslims who do not attack Muslims on the grounds of their religion nor drive Muslims from their homes. Because they see Centrism as uniquely fundamental to Islam, Centrist thinkers remain keenly sensitive to shifting realities on the ground. AlQaradawi appropriately views the entire nonMuslim world as dār al'ahd by virtue of the Charter of the United Nations. Wasatiyya, however, does not equal renunciation of Jihad and routine recognition of treaties signed between Muslim majority countries and Israel.

\section{References}

1. Yusuf alQaradawi (2004) khutābuna alislāmi filașr alalmaniyy. dār alshurūq, Cairo, Egypt, pp. 158172

2. Yusuf alQaradawi (2007) albābā walislām - radd 'Imi 'ala albābā banadikt alsādis 'ashar fi kalimatihi fi almāniya allati asā'a biha ila alislām. Maktabat Wahba, Cairo, Egypt.

3. Yusuf alQaradawi (2009) fiqh aljihād dirāsa muqārana liaḥkāmihi wafalsafatihi fi daw' alqur'ān walsunna maktabat wahba, Cairo, Egypt, 1: 239254.

4. (1986) A good discussion on the Quranic concept of peace can be found in: Earl Waugh, Peace as Seen in The Qur'ān. Ecumenical Institute, Jerusalem, Israel.

5. Nathan C Funk, Abdul Aziz Said (2009) Jalāl alMurshid, alsalām walharb filislām: Islam and Peacemaking in the Middle East. Lynne Rienner, London, UK, p. 6162.

6. For more on this leitmotif surrounding ghazwat alkhandaq (2005) (The Battle of the Trench) see: Sa'id Ramaḍān al Būṭi, fikh alsīra alnabawiyya, dār alfikr almu'āșir, Beirut, Lebanon.

7. For further analysis of the interpretative dispute surrounding the Hudaybiyya precedent (2008) Yitzhak Reiter, War, Peace and International Relations in Contemporary Islam: Muslims Scholars on Peace Accords with Israel (Jerusalem: The Jerusalem Institute for Israel Studies, p. 5870.

8. Broadly discussing the proscription against killing civilians in war is Wahba alZuhayli, 'āthār alḥarb dirāsa fikhiyya muqārana. dār alfikr (2009) Damascus, Syria, pp. 526536.

9. Kister MJ Call Yourselves By Graceful Names p. 12.

10. Reiter 19.

11. Earle H Waugh, "Peace”, Encyclopaedia of the Qur'ān 4: 3335.

12. Muhammad Mutawalli alSha'rawi, ḥawāțir muhammad mutawalli alsha'rāwi.

13. Muhammad Sayyid Tantawi, alwast fi tafsir alqur'ān alkarim.

14. Yusuf alQaradawi, fiqh aljihād, 1: 239254.
15. The semantics of silm can be gleaned from additional verses in the Quran, such as Surat alBaqara, 2: 208

16. Ibn Jarir alTabari, jāmi` albayān fi tafsir alqur'ān.

17. Fakhr alDin alRāzi, altafsir alkabir (=mafātīh alghayb): www.altafsir. com. Tusi, altibyān aljāmi li íulūm alqur'ān.

18. Ibn Kathir (1969) tafsir alqur'ân al'azịm: On the Hudaybiyyah Treaty and its wording see: Majid Khadduri, War and Peace in the Law of Islam. The Johns Hopkins Press, ; Fourth Printing, Baltimore, Marylan, USA, pp. 210213.

19. AlBayḍāwi, anwār altanzīl wa'asrār alta'wīl: www.altafsir.com. AlAlūsi, Rūh alMa`āni.

20. Ibn Jarīr alTabari, jāmi` albayān fi tafsir alqur'ān.

21. AlShawkāni, fath alqadir. AlSuyūti, aldurr almanthūr filtafsir bilma'thūr The juridical opinion that alAnfāl 8, 61 was abrogated (mansukh) by Muhammad 47, 35 can be found in: al Qurtubi, aljāmic li'ahkām alqur'ān; Ali Ibrāhim alQummi, tafsir alqur'ān; AlShawkāni, fatḥ alqadir; Al Suyūti, aldurr almanthūr.

22. AlTabari (A tradition attributed to alMujāhid). AlRāzi (He opines that the fact that the verse descended with regards to the two tribes mentioned does not preclude its universal application. AlQurțubi (He remarks that the verse relates to Banū Qurayza, as they accepted the poll tax, or Jizya, while the mushrikūn, or idolaters, demurred). AlBaydāāwi. AlShawkāni. AlTanțāwi (He remarks that according to an oral tradition ascribed to alMujāhid the verse descended with regards to Banū Qurayza, but the fact remains uncertain since the context that surrounds the verse is wholly the Battle of Badr). AlAlūsi (The verse relates to ahl alkitāb, in the same vein as verses 56 and 60 . AlSuyūți.

23. AlRāzi, Wwurūduhā fihim lā yamna'u min ijrā'ihā 'ala țāhir 'umūmihā.

24. AlTantawi, Ibn Ashur, altahrīr waltanwīr. AlAlūsi (The verse applies to infidels generally, but is abrogated by the Sword Verse, 'Āyat alSayf (Sūrat alTawba 9, 5), for the polytheists must choose between Islam and the Sword, whereas the People of the Book may pay the jizya tax levied by the Muslim ruler in accordance with the Muslim interest.

25. For more on the socalled "Sword Verse" and the abrogative power of the Barā'a declaration in Sūrat alTawba (also justly styled Surat alBarā'a) (1984) Uri Rubin, Barā’a: A Study of Some Quranic Passages, JSAI 5: 1332.

26. Uri Rubin "On the Question of the Unity of the Qur'ān: A General View" in: Israeli National Academy for Sciences, Studies in Ancient Islam (from a spoken presentation on the occasion of Meir Y. Kister's $90^{\text {th }}$ birthday). Jerusalem, Israel, p. 83.

27. AlZamakhshari, alkashshāf.

28. AlBaghawi, ma ālim altanzīl, Full text of Mamoun's fatwa: Reiter, p. 72 78; pp. 178182. Full text of the juridical ruling: Reiter, 85107. 190205, Reiter, 108116; 214220.

29. Yusuf alQaradawi (2001) min hady alislām fatāwa mucāșira. dār alqalam, Kuwait, India, 3: 465471.

30. The full text of Ibn Baz's riposte to alQaradawi is quoted in: Reiter, pp. 217218.

31. Yusuf alQaradawi, fiqh aljihād (2002) 10931105. Yusuf alQaradawi, alqa'ida qadiyyat kull muslim (Beirut: almaktab alislāmi 2: 4252.

32. Ilai Alon (2007) Idiom of the Arab Peace Initiative in: Kobi Michael (ed.), Arab League Peace Initiative - A Historic Opportunity? Background, Meanings, and Possible Avenues of Exploration (Jerusalem: The Jerusalem Institute for Israel Studies).

33. Yusuf alQaradawi, fiqh aljihād, 1(239240): 1315.

34. Yusuf alQaradawi, fiqh aljihād, 2: 255257. 


\section{Global Journal of Archaeology \& Anthropology}

35. Yusuf alQaradawi, fiqh aljihād, 1: 239246.

36. Ali b. Nafi al'Ulyani, ahammiyyat aljihād fi nashr alda'wa alislāmiyya walradd 'ala altawā’if alḍālla fihi (Saudia: dār țayyiba, 1995).

37. Reiter p. 4051.

38. Reiter p. 4142.

39. Wahba alZuhayli, 'āthār alḥarb dirāsa fikhiyya muqārana Damascus: dār alfikr, (2009) 655674. Further reading on wasatiyya thinking: Yusuf alQaradawi, kalimāt filwasațiyya alislāmiyya wa ma‘ālimiha (Cairo: dār alshurūq, 2008), 4156; Bettina Gräf, The Concept Of Wasatiyya In The Work Of Yusuf AlQaradawi in: Bettina Gräf and Jakob SkovgaardPeterson (editors), Global Mufti - The Phenomenon Of Yusuf al Qaradawi (New York: Columbia University Press, pp. 213238

40. The fatwa in which Abu Basir alTartusi indicts alQaradawi.

41. On alQaradawi's ties to the Muslim Brotherhood (2009) Husam Tammam, "Yusuf alQaradawi And The Muslim Brothers: The Nature Of A Special Relationship" in: Bettina Gräf and Jakob SkovgaardPeterson (editors), Global Mufti - The Phenomenon Of Yusuf alQaradawi, Columbia University Press, New York, USA, p. 5583.

42. Yusuf alQaradawi, fiqh aljihād 2: 1038.

43. Yusuf alQaradawi, kalimāt filwasațiyya alislāmiyya wama‘ālimiha Cairo: dār alshurūq (2008), p. 4156; Akram, Kussab, ma‘̄āim alwasatiyya 'ind alqaraḍ̄ani, a research paper submitted to a conference hosted by the Ministry of Religious Endowment in Gaza October 12 2010 entitled "Efforts by Dr. AlQaradawi on behalf of Islam and support of the Palestinian Cause"; Abd alQadir Khalil alShatali, alqaradawi faqīh alwasațiyya wa mukāfaḥat alghuluww, also delivered at the aforementioned conference; Bettina Gräf, The Concept of Wasatiyya in the Work of Yusuf alQaradawi in: Bettina Gräf and Jakob SkovgaardPetersen (ed.), Global Mufti - The Phenomenon Of Yusuf alQaradawi. Columbia University Press, New York, USA, pp. 213238.

44. Yusuf alQaradawi (2008) kalimāt filwasaṭiyya alislāmiyya wama‘ālimiha. dār alshurūq, Cairo, Egypt, p. 47.

45. Yusuf alQaradawi (2009) fiqh aljihād dirāsa muqārana liaḥkāmihi wafalsafatihi fi daw' alqur'ān walsunna (Cairo: maktabat wahba 2: 10381040 .

46. Yusuf alQaradawi, fiqh aljihād 2: 785792.

47. Yusuf alQaradawi, fiqh aljihād 1: 267314.

48. Yusuf alQaradawi, fiqh aljihād 1: 267314.

49. Yusuf alQaradawi, fiqh aljihād 2: 787.

50. Yusuf alQaradawi, fiqh aljihād 2: 879910.

51. Wahba alZuhayli, 'āthār alḥarb, pp. 190213.

52. Majid Khadduri p. 5154.
53. Abdullah b. Yusuf alJadi', taqsīm alma'mūra fi alfikh alislāmi wa'athruhu filwāqi.

54. Yusuf alQaradawi, fiqh aljihād 2: 900.

55. Yusuf alQaradawi, fiqh aljihād 2: 901906.

56. Yusuf alQaradawi, fiqh aljihād 2: 906908.

57. Reuven Paz (1992) The Position Of The Radical Islamic Movements Towards The Jews And Zionism In Our Generation" in: Institute For Peace Research At Givat Haviva, Islam And Peace - Islamic Approaches To Peace In The Contemporary Arab World (, 4546, Givat Haviva, Reiter p. 5155.

58. Yusuf alQaradawi, fiqh aljihād dirāsa muqārana liaḥkāmihi wafalsafatihi fi ḍaw' alqur'ān walsunna

59. Maktabat wahba (2009) Cairo, Egypt 1: 1219.

60. Thomas Hegghammer, "JihadiSalafis Or Revolutionaries? On Religion And Politics In The Study Of Militant Islamism" in: Roel Meijer (ed.), Global Salafism - Islam`s New Religious Movement, New York, Columbia University Press, USA, pp. 251257.

61. For more on Muhammad alMaqdisi, see: Joas Wagemakers, "A Purist JihadiSalafi: The Ideology of Abu Muhammad alMaqdisi," British Journal of Middle Eastern Studies, 36 (2): 281297.

62. Abu Muhammad alMaqdisi, khalāșat alkalām fi fitnat alislām, Minbar alTawhīd waljihād at http://www.tawhed.ws.

63. http://www.tawhed.ws/FAQ/display_question?qid=120.

64. Philipp Holtmann (2009) Abu Musab Al Suri`s Concept, Tel Aviv University, Israel.

65. Reuven Paz, "Debates Within The Family: JihadiSalafi Debates On Strategy, Takfir, Extremism, Suicide Bombings And The Sense Of The Apocalypse" In: Roel Meijer (Eds.), Global Salafism - Islam`s New Religious Movement. New York: Columbia University Press, USA, pp. 267269.

66. Bernard Haykel, "On The Nature Of Salafi Thought And Action" in: : Roel Meijer (ed.), Global Salafism - Islam`s New Religious Movement. New York: Columbia University Press, USA, p. 39.

67. Markaz alMisbār lilDirāsāt walBuhūth (2011) alsalafiyya aljihadiyya: dār alislām wadār alkufr (Dubai: Markaz almisbār, p.1819.

68. On alwalā' walbarā', Ayman alẒawahiri, alwalā' walbarā': 'aqīda manqūla wawāqi' mafqūd.

69. http://hanein.info/vb/showthread.php?t=137783.

70. Abd alRahmān b. Abd alKhāliq, ḥukm mu'āhadāt alṣulh walsalām maca alyahūd wamawqif al muslim minha.

71. Abd Allāh 'Azzām, aldifāc ‘an arāḍi almuslimīn 'ahamm furūḍ al'a'yān, p. 3941. 
This work is licensed under Creative Commons Attribution 4.0 License

DOI: 10.19080/GJAA.2018.05.555653

\section{Your next submission with Juniper Publishers will reach you the below assets}

- Quality Editorial service

- Swift Peer Review

- Reprints availability

- E-prints Service

- Manuscript Podcast for convenient understanding

- Global attainment for your research

- Manuscript accessibility in different formats ( Pdf, E-pub, Full Text, Audio)

- Unceasing customer service

Track the below URL for one-step submission https://juniperpublishers.com/online-submission.php 